\title{
FLORISTIC CHARACTERIZATION OF IBURA NATIONAL FOREST, SERGIPE, BRAZIL
}

\author{
CARACTERIZAÇÃO FLORÍSTICA DA FLORESTA NACIONAL DO IBURA, \\ SERGIPE, BRASIL
}

\section{José Paulo SANTANA ${ }^{1}$; Patrício Adriano da ROCHA ${ }^{1}$; Thalita Rocha da SILVA²; Adauto de Souza RIBEIRO ${ }^{1}$; Ana Paula do Nascimento PRATA ${ }^{3}$}

1. Universidade Federal de Sergipe - UFS, Laboratório Biologia da Conservação, Departamento de Biologia, São Cristóvão, SE, Brazil. jpaulosantana-bio@hotmail.com; 2. Universidade Federal de Sergipe - UFS, Graduate in Ciências Florestal, São Cristóvão, SE, Brazil; 3. Universidade Federal de Alagoas, Centro de Ciências Agrárias. Rio Largo, AL, Brasil.

\begin{abstract}
The aim of this study was to obtain information on the floristic composition and dispersal syndromes of the Ibura National Forest and carry out an analysis of similarity with other floristic surveys in the state of Sergipe. For this purpose, bimonthly sampling was carried out from September 2012 to December 2014. Total of 328 species were recorded, of which 324 were angiosperms belonging to 82 families, followed by three species of ferns and lycophytes and one species of Gymnosperm. Sixty-seven new species were recorded for the state of Sergipe. The richest families in species were Fabaceae, Myrtaceae, Rubiaceae, Asteraceae, Euphorbiaceae and Malvaceae. Regarding the dispersal syndromes, the dominance of zoochoric dispersal was observed, followed by autochoric and anemochoric dispersal. Among the tree and shrub species, the zoochoric syndrome was predominant (70\%), while herbaceous species showed predominance of autochoric species (49\%), and climber species have a more equitable proportion among the syndromes (38\% autochoric, 32\% anemocoric and 30\% zoochoric). The Ibura National Forest presented relatively low levels of similarity with other sites located in the Atlantic Forest, possibly influenced by its isolation and distance between fragments. As we found in the Ibura National Forest, the dominance of zoochoric species was also observed in other studies conducted in the Atlantic Forest. The results of this study indicate that the Ibura National Forest is refuge to a high diversity of plant species of the Atlantic Forest, being a fairly heterogeneous area, which is still understudied.
\end{abstract}

KEYWORDS: Atlantic Forest. Brazilian northeast. Diversity. Flora.

\section{INTRODUCTION}

The Atlantic Forest is one of the 34 global biodiversity hotspots (MITTERMEIER et al., 2004). This domain has an estimated number of 20000 species of vascular plants (PINTO et al., 2006), of which $6663(49 \%)$ are considered to be endemic (STEHMANN et al., 2009). Originally, the Atlantic Forest extended continuously along the Brazilian coast, penetrating into eastern Paraguay and northeastern Argentina in its southern portion (TABARELLI et al., 2005), and was considered the second largest tropical rainforest in the American continent. Currently, if we include all the fragments of native forest above 3 hectares and the non-forest formations such as salt marshes and mangroves, only $15 \%$ of the Atlantic Forest remains (FUNDAÇÃO SOS MATA ATLÂNTICA, 2014), covering a variety of climatic zones and vegetation formations of the tropical to subtropical regions (TABARELLI et al., 2005).

With regard to conservation, the largest and most important remnants are usually associated with full protection conservation units, mainly located on the coast of the states of Santa Catarina, Paraná, São Paulo, Rio de Janeiro, Bahia and the mountain region of Espírito Santo, corresponding to less than $2 \%$ of the biome's area (PINTO et al., 2006).

In the state of Sergipe, it is estimated that only $9 \%$ of the original area of the Atlantic Forest remains (FUNDAÇÃO SOS MATA ATLÂNTICA; INPE, 2002). The state has only nine conservation units for the Atlantic Forest biome and not all native vegetation fragments are included in these units (SOUZA; LANDIM, 2007).

Among the conservation units of the state of Sergipe, the Serra de Itabaiana National Park (7966 ha), Santa Isabel Biological Reserve (2766 ha), and Mata do Junco Wildlife Refuge (600 ha) are noted for being among the largest units of the state (MENDES; GOMES; ALVEZ, 2010; SOUZAALVES et al., 2014; OLIVEIRA; LAMDIM, 2014). But the vast majority of remnants are still in private areas, such as Mata do Crasto, located in the southern region. The latter is considered the most representative and preserved fragment of Atlantic Forest of the state, covering an area of approximately 1000 ha (LANDIM et al., 2015).

Floristic studies are starting points for understanding biological ecosystems to advance our knowledge about the complex dynamic behavior of plant communities (MARANGON; SOARES; 
FELICIANO, 2003). Besides the species composition, the understanding of the functional structure of each forest remnant, such as of the set of dispersal syndromes (PRADO-JÚNIOR et al. 2014), is essential to define its conservation status, which is reflected, among other factors, in the complexity of animal-plant interactions (VAN DER PIJL, 1982).

The Sergipe fragments are a refuge to a wide diversity of flora and fauna including some endangered species, such as Campomanesia viatoris (Myrtaceae) (LANDIM; LANDRUM, 2002), Manilkara maxima, Pouteria macahensis and Pouteria nordestinensis (Sapotaceae) (PRATA; FARIAS; LANDIM, 2015), which reinforces the importance of studying them. Despite advances in floristic studies in the last decade, so far, few remnants have been systematically inventoried in the state of Sergipe (VICENTE et al., 2005; MENDES; GOMES; ALVEZ, 2010; SANTOS, 2011; SOUZA-ALVES et al., 2014; PRATA et al., 2013; LANDIM et al., 2015).

Studies of flora are considered fundamental for basing any activities regarding the use, recovery and conservation of tropical forests (RIBAS et al., 2003). This study was developed to inventor the floristic composition and characterizing the dispersal syndromes of the Ibura National Forest and assessing its similarity to other floristic surveys in the state. Considering that the Ibura National Forest does not yet have a management plan, this study could also potentially contribute to its development.

\section{MATERIAL AND METHODS}

\section{Study area}

Before the creation of the Ibura National Forest (FLONA Ibura), this area was used to support the development of livestock farming in the state of Sergipe (Horto Ibura) and later to support recovery projects of degraded areas. It was transformed into a sustainable conservation unit by September 2005.

The Ibura National Forest $\left(10^{\circ} 83^{\prime} 86.0^{\prime \prime} \mathrm{W}\right.$, $37^{\circ} 13^{\prime} 42.0^{\prime \prime} \mathrm{S}$ ) covers an area of approximately 145 ha and is located in the municipality of Nossa Senhora do Socorro, in the state of Sergipe. It is classified as semideciduous forest, at medium and advanced stages of regeneration, associated with mangroves (Figure 1) (BRASIL, 2005).

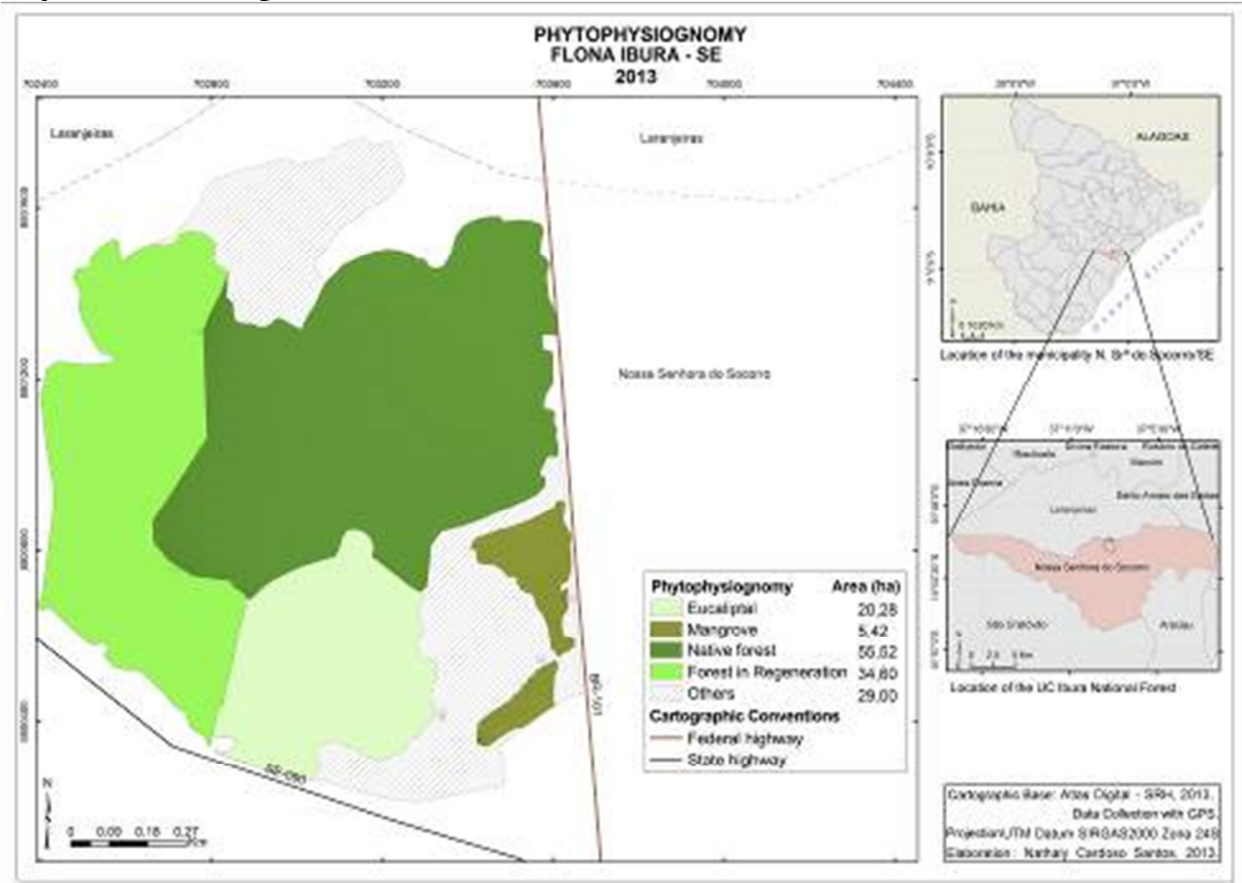

Figure 1. Location of the study area, Ibura National Forest, in the municipality of Nossa Senhora do Socorro, state of Sergipe, Brazil.

In general, the vegetation of the Ibura National Forest is quite peculiar, having a history of deforestation for eucalyptus plantation, introduction of exotic species and anthropic pressure. It presents four main vegetation types: (i) a preserved forest area (on the margins of the BR101 highway) with a canopy in an advanced state of succession when compared to the other subareas; (ii) an area under regeneration, with an understory in secondary succession stage mixed with an old abandoned eucalyptus plantation; (iii) a mangrove area along the margins of Cotinguiba River, with a small spot 
on the east margin of the BR101 highway ; (iv) an open area, characterized by sparse grasses and shrubs. Several trails were also found surrounding the area and inside it, some of which were approximately $5 \mathrm{~m}$ wide.

\section{Floristic survey}

To study the vegetation structure and composition of a particular type of vegetation, it is important that the sample is representative, namely that the procedures and methods used for forest measurement are compatible with the vegetation, and cover a significant portion of its flora. Initially, a visit for recognition of the area was conducted. This led to the choice of a method for obtaining data on floristic characterization that included random sampling along the edge of the forest and along existing trails inside the forest. Sampling was carried out twice a month, from September 2012 to December 2015.

In the field, the species collected were categorized as shrubs, trees, herbaceous, climber, epiphyte and semiparasites (GONÇALVES; LORENZI, 2011). The definition of the dispersal syndromes (anemochoric, autochoric, epizoochoric, hydrochloric and zoochoric) was based on the external morphology of the fruits and seeds (VAN DER PIJL, 1982; SARAVY et al., 2003).

The collected material was pressed in the field, according to Martins-da-Silva et al. (2014) and identified through specialized literature, assistance from experts, and comparisons to preexisting herbarium specimens. It was subsequently deposited in the Herbarium ASE - Federal University of Sergipe.

\section{Analyses}

From the Jaccard similarity index, a cluster analysis was performed using the unweighted pair group method with arithmetic mean (UPGMA). As some of the studies that were used for the comparison did not sampled herbaceous species of Atlantic Forest (SOUZA-ALVES et al., 2014; VICENTE et al., 2005; OLIVEIRA et al., 2013; LANDIM et al., 2015) and Caatinga (SILVA; PRATA; MELLO, 2013; FONSECA, 1991; FERREIRA，2011; NOGUEIRA-JÚNIOR，2011; MACHADO; PRATA; MELLO, 2012), in this analysis only tree and shrub species were considered. The analyses were performed using the program PAST (HAMMER; HARPER; RYAN, 2001). The composition of tree and shrub species at the Ibura National Forest were compared with other floristic studies in the state of Sergipe carried out both in the Atlantic Forest and in the Caatinga (Table 1).

\section{RESULTS}

The study area presented a total of 328 species, of which 324 were Angiosperms belonging to 82 families; three were species of ferns from three families and one was a Gymnosperm. Of this total, the 11 families with the greatest species richness were Fabaceae (standing out with 50 species in 30 genera), followed by Myrtaceae (20 species in 7 genera), Rubiaceae (15 species in 11 genera), Asteraceae (14 species in 14 genera), Euphorbiaceae (13 species in 9 genera), Malvaceae (12 species in 8 genera), and Orchidaceae (12 species in 12 genera). These families comprised approximately $26 \%$ of the species found (Appendix $1)$.

Among the 324 species of Angiosperms sampled in the Ibura National Forest, 286 are native species, 14 exotic species, 18 naturalized species and six cultivated species (Appendix 1). Among the native species, 22 are endemic to the Atlantic Forest and to the northeast of Brazil (Caatinga and Cerrado), according to the classification of the List of the Brazilian Flora (LSBF; http://floradobrasil.jbrj.gov.br/).

Among the sampled species, one of the genus Zanthoxylum (Rutaceae) has not been described before our fieldwork. This new species is endemic of Sergipe (see GROPPO; ERBERT, 2015) (Figure 2). Moreover, the presence of Catasetum uncatum Rolfe (Orchidaceae) in the study area, categorized as "Near Threatened" (LSBF; http://floradobrasil.jbrj.gov.br/), as well as 79 new cases of native species for the state of Sergipe, among them Annona montana (Anonaceae), Cayaponia tayuya (Cucurbitaceae), Cupania oblongifolia and Paullinia revoluta (Sapindaceae), Diospyros inconstans (Ebenaceae), Drymonia serrulata (Gesnariaceae), Inga laurina and Swartzia dipetala (Fabaceae), Passiflora mansoi (Passifloraceae), Piper amalago (Piperaceae) and Varronia globosa (Boraginaceae) are important findings for the state ((Appendix 1; Figure 2). Three native species of ferns were also recorded: Lygodium venustum (Lygodiaceae), Serpocaulon $\mathrm{sp}$ (Polypodiaceae) and Vittaria lineata (Pteridaceae), being the first record of the occurrence of the genera for the state (Appendix 1). 

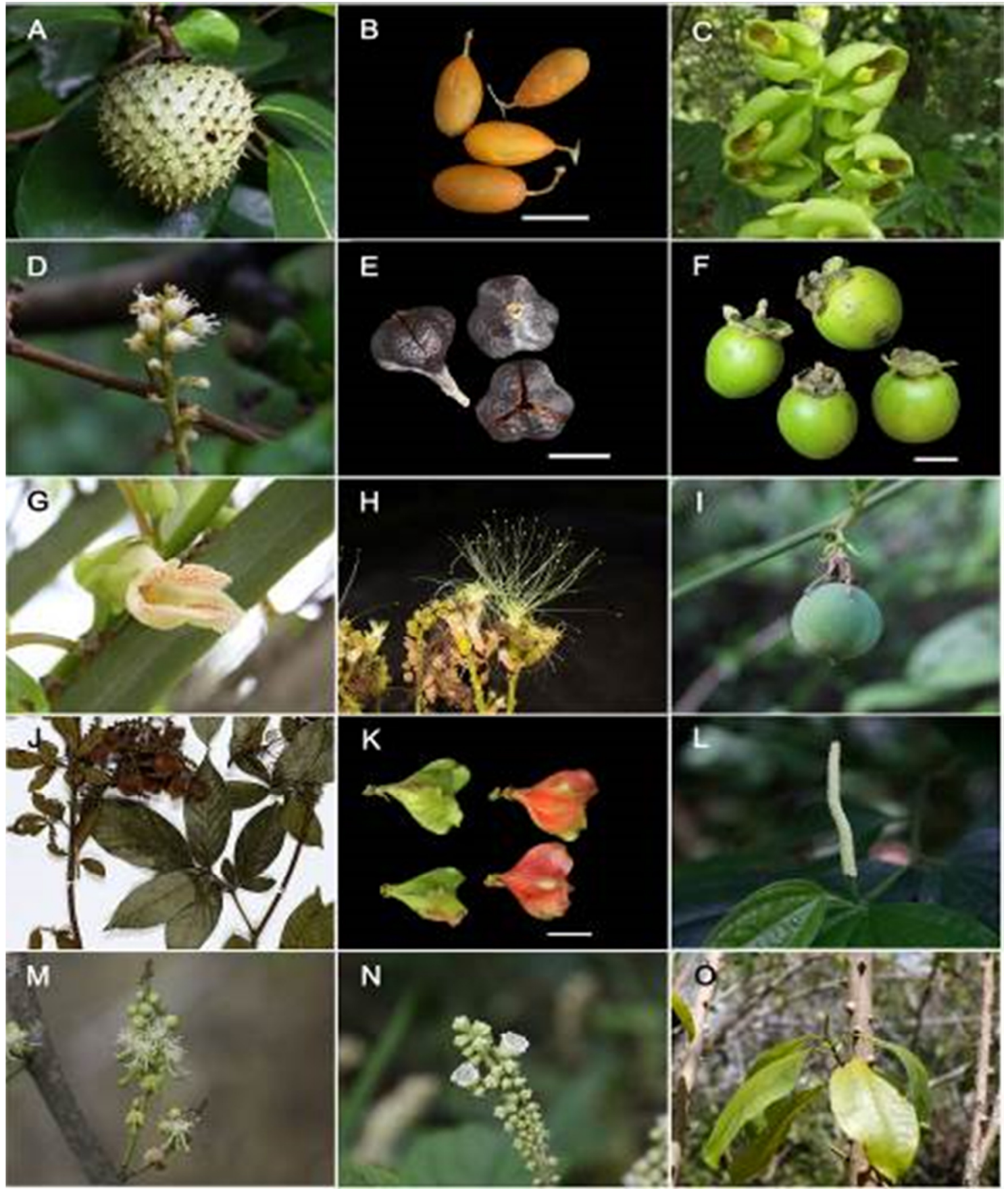

Figure 2. Some of the new occurrences of species found in the Ibura National Forest, state of Sergipe, Brazil. A: Annona montana (Fruit). B: Cayaponia tayuya (Fruits). C: Catasetum uncatum (Near Threatened) (Flower). D and E: Cupania oblongifolia (Flowers and Fruits). F: Diospyrus inconstans (Fruits). G: Drymonia serrulata (Flower). H: Inga laurina (Flower). I: Passiflora mansoi (Fruit). J and K: Paullinia revolute (Fruits). L: Piper amalago (Inflorescence). M: Swartzia dipetala (Flowers). N: Varronia globosa (Flowers). O: Zanthoxylum sp (New Species). Scales bars $=20 \mathrm{~mm}$ in B, E. $10 \mathrm{~mm}$ in F, K. Photos by J.P. Santana.

In some areas of the Ibura National Forest, some exotic species were predominant, such as Pinus caribaea (Pinaceae), Mangifera indica (Anacardiaceae), Artocarpus heterophyllus e Ficus cf. nitida (Moraceae), Terminalia catappa
(Combretaceae) and Musa paradisiaca (Musaceae). The herbaceous habit dominated, with 124 species, followed by shrubs (74), trees (66), climber (51), semiparasites (11), one parasite and one epiphyte habits (Appendix 1). 
Seed dispersal by animals was most observed (48\%; $156 \mathrm{spp}$ ), followed by autochoric dispersal (25\%; $83 \mathrm{spp})$, anemochoric dispersal (23\%; $74 \mathrm{spp})$ and epizoochoric, hydrochoric and others dispersal (4\%; $15 \mathrm{spp})$. Among the tree species (66 spp), $45 \mathrm{spp}(69 \%)$ are zoochoric, 12 (19\%) autochoric and $8(12 \%)$ anemochoric. This proportion is similar to that presented by shrub species, 58 (79\%) zoochoric, followed by autochoric $(8 ; 12 \%)$ and anemochoric (7 spp; $8 \%)$. On the other hand, herbaceous (124 spp) showed predominance of autochoric species (42\% autochoric, $29 \%$ anemocoric and $29 \%$ zoochoric) and climber species (51 spp) had a more equitable proportion between the syndromes (38\% autochoric, 32\% anemocoric and $30 \%$ zoochoric). Together, tree and shrub represent $67 \%$ species zoochoric in the FLONA Ibura.

Among the eleven richest families, six are characterized as zoochoric by having fleshy mesocarp that attracts wildlife, enabling dispersal, such as Myrtaceae (18), Fabaceae (15), Rubiaceae (14), Boraginaceae (7), Sapindaceae (7) and Euphorbiaceae (6). The families Fabaceae (31), Malvaceae (8), Euphorbiaceae (8) and some Acanthaceae (4) are mostly autochoric, characterized by the presence of species with dry pericarp, while Asteraceae (13), Orchidaceae (12), Cyperaceae (8) and Apocynaceae (8) have mostly anemochoric species (Appendix 1).

Some families showed more than one type of syndrome, such as Euphorbiaceae with zoochoric and autochoric species, followed by Malvaceae with three types of syndromes and Fabaceae, with four types of syndromes (zoochoric, autochoric, anemochoric and epizoochoric), with dominance of autochoric (31 species) and zoochoric (15) species (Appendix 1).

Comparing the floristic composition with inventories already carried out in the state, the similarity showed two large clusters, the first belongs to the Atlantic Forest (AF) (11-24\%) and the other to the Caatinga (CA) $(18-41 \%)$. Species richness of the Ibura National Forest, grouped with other studies located on the site of the Atlantic Forest (AF), however they presented relatively low similarity levels (11-19\%). The site that showed the highest similarity to the Ibura National Forest was the Piauitinga River Basin (4), municipality of Salgado, (with 19\%) and Serra de Itabaiana PN (5) (with 15\%) (Figure 3; Table 1).

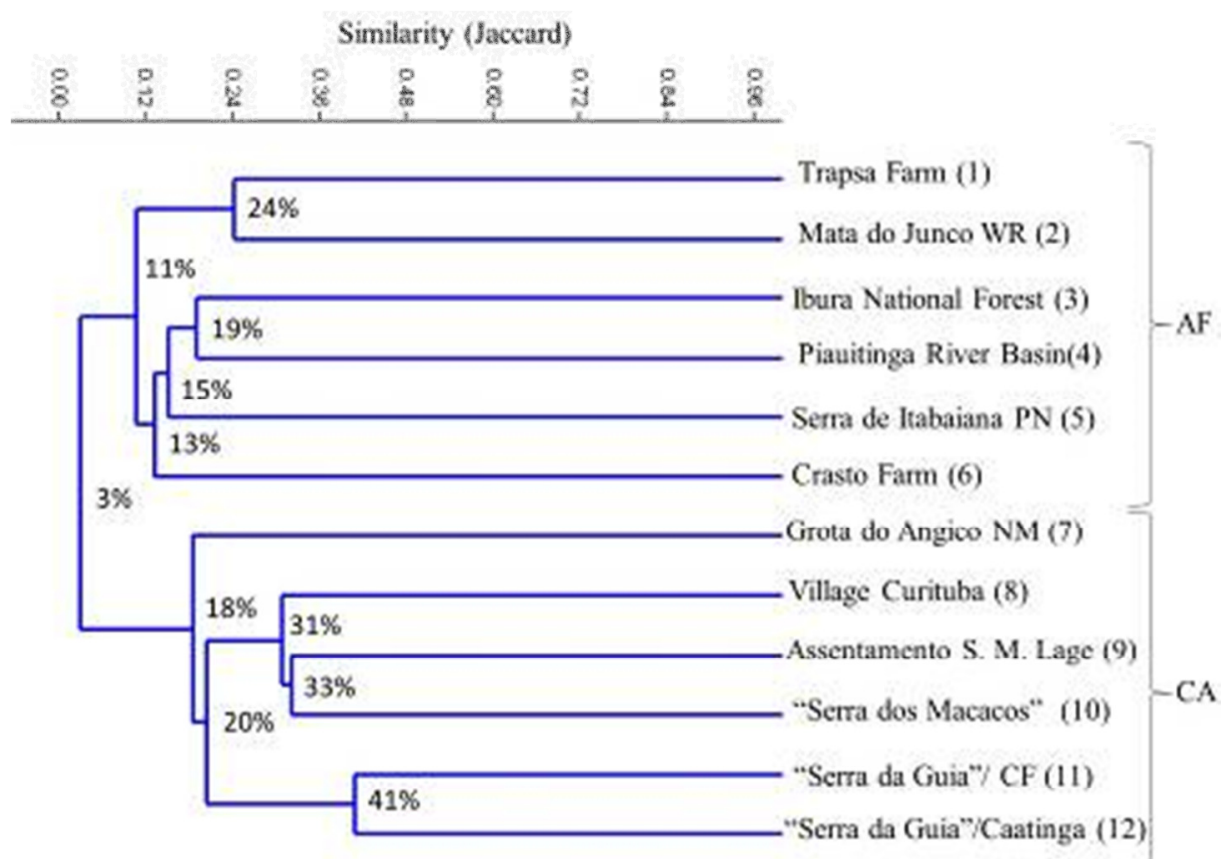

Figure 3. Cluster analysis based on the Jaccard florisitic similarity index of tree and shrub species in the state of Sergipe. Numerical codes are the same as those in Table 2. Legend: AF = Atlantic Forest; $\mathrm{CA}=$ Caatinga. 
Table 1. Data used in the Cluster analysis, based on floristic similarity (Jaccard index) of sites sampled in Sergipe, Brazil.

\begin{tabular}{|c|c|c|c|c|c|c|}
\hline Code & Locality & Municipality & Richness & $\begin{array}{l}\text { Selected } \\
\text { Species }\end{array}$ & Coordinates & References \\
\hline 1 & Trapsa Farm & $\begin{array}{l}\text { Itaporanga } \\
\text { d'Ajuda }\end{array}$ & 83 & 83 & $\begin{array}{l}11^{\circ} 12^{\prime} 00.0^{\prime \prime} \mathrm{S}, \\
37^{\circ} 14^{\prime} 00.0^{\prime \prime} \mathrm{W}\end{array}$ & $\begin{array}{c}\text { SOUZA-ALVES et } \\
\text { al. } 2014 .\end{array}$ \\
\hline 2 & $\begin{array}{l}\text { Mata do Junco } \\
\text { Wildlife Refuge }\end{array}$ & Capela & 42 & 42 & $\begin{array}{l}10^{\circ} 32^{\prime} 00.0^{\prime \prime} \mathrm{S}, \\
37^{\circ} 03^{\prime} 30.0^{\prime \prime} \mathrm{W}\end{array}$ & $\begin{array}{c}\text { SOUZA-ALVES et } \\
\text { al., } 2014 .\end{array}$ \\
\hline 3 & $\begin{array}{l}\text { Ibura National } \\
\text { Forest }\end{array}$ & $\begin{array}{l}\text { Nossa Senhora } \\
\text { do Socorro }\end{array}$ & 328 & 128 & $\begin{array}{l}10^{\circ} 83^{\prime} 86.0^{\prime \prime} \mathrm{W}, \\
37^{\circ} 13^{\prime} 42.0^{\prime \prime} \mathrm{S}\end{array}$ & Current Study \\
\hline 4 & $\begin{array}{l}\text { Piauitinga River } \\
\text { Basin }\end{array}$ & Salgado & 101 & 80 & $\begin{array}{l}11^{\circ} 09^{\prime} 57.0^{\prime \prime} \mathrm{S}, \\
37^{\circ} 32^{\prime} 51.0^{\prime \prime} \mathrm{W}\end{array}$ & $\begin{array}{l}\text { OLIVEIRA et al., } \\
2013 .\end{array}$ \\
\hline 5 & $\begin{array}{l}\text { Serra Itabaiana } \\
\text { National Park }\end{array}$ & Itabaiana & 114 & 92 & $\begin{array}{l}10^{\circ} 45^{\prime} 07.0^{\prime \prime} \mathrm{S}, \\
37^{\circ} 20^{\prime} 28.0^{\prime \prime} \mathrm{W}\end{array}$ & $\begin{array}{l}\text { VICENTE et al., } \\
2005 .\end{array}$ \\
\hline 6 & Crasto Farm & $\begin{array}{l}\text { Santa Luzia do } \\
\text { Itanhy }\end{array}$ & 324 & 178 & $\begin{array}{l}11^{\circ} 22^{\prime} 00.0^{\prime \prime} \mathrm{S}, \\
37^{\circ} 25^{\prime} \mathrm{W}\end{array}$ & LANDIM et al., 2015 \\
\hline 7 & $\begin{array}{l}\text { Grota do Angico } \\
\text { Natural Monument }\end{array}$ & Canindé & 174 & 42 & $\begin{array}{l}09^{\circ} 39^{\prime} 56.0^{\prime \prime} \mathrm{S}, \\
37^{\circ} 41^{\prime} 06.9^{\prime \prime} \mathrm{W}\end{array}$ & $\begin{array}{l}\text { SILVA; PRATA; } \\
\text { MELLO, } 2013 .\end{array}$ \\
\hline 8 & Village Curituba & $\begin{array}{l}\text { Poço Redondo } \\
\text { e Canindé }\end{array}$ & & 38 & $\begin{array}{l}09^{\circ} 51^{\prime} 00.0^{\prime \prime} \mathrm{S}, \\
37^{\circ} 37^{\prime} 00.0^{\prime \prime} \mathrm{W}\end{array}$ & FONSECA, 1991. \\
\hline 9 & $\begin{array}{l}\text { Assentamento } \\
\text { Santa Maria da } \\
\text { Lage }\end{array}$ & Poço Verde & 176 & 63 & $\begin{array}{l}10^{\circ} 42^{\prime} 11.0^{\prime \prime} \mathrm{S}, \\
38^{\circ} 11^{\prime} 06.0^{\prime \prime} \mathrm{W}\end{array}$ & FERREIRA, 2011. \\
\hline 10 & $\begin{array}{l}\text { "Serra dos } \\
\text { Macacos" }\end{array}$ & Tobias Barreto & 93 & 53 & $\begin{array}{l}10^{\circ} 52^{\prime} 52.0^{\prime \prime} \mathrm{S} \\
37^{\circ} 59^{\prime} 12.0^{\prime \prime} \mathrm{W}\end{array}$ & $\begin{array}{l}\text { NOGUEIRA- } \\
\text { JÚNIOR, } 2011 .\end{array}$ \\
\hline 11 & $\begin{array}{l}\text { "Serra da Guia"/ } \\
\text { Cloud Forest }\end{array}$ & Poço Redondo & 284 & 68 & $\begin{array}{l}09^{\circ} 58^{\prime} 00.0^{\prime \prime} \mathrm{S}, \\
37^{\circ} 52^{\prime} 00.0^{\prime \prime} \mathrm{W}\end{array}$ & $\begin{array}{c}\text { MACHADO; } \\
\text { PRATA; MELLO, } \\
2012 .\end{array}$ \\
\hline 12 & $\begin{array}{l}\text { "Serra da Guia"/ } \\
\text { Caatinga }\end{array}$ & Poço Redondo & 238 & 56 & $\begin{array}{l}09^{\circ} 58^{\prime} 00.0^{\prime \prime} \mathrm{S} \\
37^{\circ} 52^{\prime} 00.0^{\prime \prime} \mathrm{W}\end{array}$ & $\begin{array}{c}\text { MACHADO; } \\
\text { PRATA; MELLO, } \\
2012 .\end{array}$ \\
\hline
\end{tabular}

\section{DISCUSSION}

The families with greater richness of species found at the Ibura National Forest (Fabaceae, Myrtaceae, Rubiaceae, Asteraceae and Euphorbiaceae) are similar to those found in other surveys conducted in the Atlantic Forest of the state of Sergipe (VICENTE et al., 2005; SANTOS, 2011; MENDES; GOMES; ALVEZ, 2010; SOUZAALVES et al., 2014; LANDIM et al., 2015). The Ibura National Forest is also distinguished by the high species richness of native and endemic species in the state, even within a smaller area, when compared to the previously mentioned studies.

About $24 \%$ of the native species found in FLONA Ibura (79 spp.) are considered new records for the state of Sergipe. This set of new records for the state can be divided into four categories, according to their distribution areas known: (i) Swartzia dipetala (Fabaceae) and Parodiolyra ramosissima (Poaceae), with known distribution limited to the Bahia Atlantic Forest remnants; (ii) Angelonia biflora (Angeloniaceae), previously recorded from Pernambuco to Ceará; (iii) species with distributions remnants of Bahia and states of the Southeast and South of Brazil (11 species); (iv) and species distribution areas between the neighboring states Sergipe (10 species) (LSBF;http://floradobrasil.jbrj.gov.br/). These endemic species, as well as the new taxon Zanthoxylum sp. (Rutaceae), need of conservation action, because besides the limited distribution, they occur in only few state fragments.

These 79 new cases records contribute to increase the knowledge about species distribution in the state, together with, PRATA et al. (2013), found 494 species in the first volume of the botanical series: Flora de Sergipe; SOUZA-ALVES et al. (2014) recorded 125 species (34 species being new records) and LANDIM et al. (2015) found 321 species, 129 of these being considered new occurrences for the Atlantic Forest of the state. It is important to note that this scenario has changed in recent years with the result of recent publications, where the number of species occurring in the state 
has been gradually updated, as well as records of ocurrence.

The presence of endemic species, as well as those in the "near threatened" category, emphasizes the importance of existing conservation units and reinforces the urgency of protecting new areas of vegetation in the state (ANDERSON, 1994; MAURER, 1994).

The high number of exotic species in FLONA (Table 2) can be connected to local historical factors such as the removal of native vegetation for eucalyptus plantation and anthropogenic actions carried out in the vicinity and in the study area. The introduction of exotic species can also be related to the former use of the space. Data on exotic species are worrying, since we have no studies in the area to find out whether they are causing damages or are bringing benefits to the native species.

Similar to the results found in the Ibura National Forest, the dominance of zoochoric species was also observed in other studies conducted in the Atlantic Forest (REYS et al., 2005; MOREIRA; QUEIROZ; PIGOZZO, 2009; OLIVEIRA et al., 2011; MOURA; DUARTE; LEMOS, 2011). The dominance of zoochoric species in rainforests is favored by the precipitation factor, enabling the development of edible fruits, favoring the dispersal by fauna (HOWE; SMALLWOOD, 1982). Within this group, the morphological variations and strategies to attract the disperser vary between species, nutrients and the amount of seeds, which contribute to the establishment of plant populations (PIZO, 2002).
The species cluster showed two main locations (CA and FA) for the two biomes that occur in the state, showing that species are key factors in the characterization of both. The species composition of the analyzed fragments showed relatively low levels of similarity, even those belonging to the same biome or those that are considerably close to each other. Furthermore, this low similarity is probably being influenced by the distance between fragments, and historical levels of degradation. FAHRIG (2003) mentions that the isolation of areas causes loss of species richness, decreases interaction, limits the population distribution, abundance, dispersion and, genetic exchanges.

The results of this study indicate that the Ibura National Forest is a refuge to a high diversity of plant species of the Atlantic Forest, being a fairly heterogeneous area, still under studied. The data reinforce the need and importance of conservation units for the preservation of regional biodiversity and highlight the need of a management plan and analysis of the exotic species in the area.

\section{ACKNOWLEDGEMENTS}

We thank CNPq and CAPES for financial support to the first author throughout the research period. We also thank the whole team and employees of the Ibura National Forest, particularly the former manager Paulo Cezar Reyes Bastos and the current manager of the unit, Ana Carolina Gomes Batista.

\footnotetext{
RESUMO: O objetivo deste estudo foi obter informações sobre a composição florística, as proporções entre as síndromes de dispersão das espécies ocorrentes na Floresta Nacional Ibura e realizar uma análise de similaridade com outros levantamentos florísticos no estado. Para isto, foi realizada uma amostragem bimestral a partir de setembro de 2012 a dezembro de 2014. Foram registradas 328 espécies, das quais 317 são Angiospermas pertencentes a 82 famílias, seguido de três espécies de samambaias e Licófitas e uma espécie de Gimnosperma. Sessenta e sete novas ocorrências foram registradas para o estado de Sergipe. As famílias mais ricas em espécies foram, Fabaceae, Myrtaceae, Rubiaceae, Asteraceae, Euphorbiaceae e Malvaceae. Quanto às síndromes de dispersão, observou-se a dominância da dispersão zoocórica, seguida por autocórica e anemocórica. Entre as espécies arbóreas e arbustivas, houve a dominância da síndrome zoocórica (70\%), em espécies herbáceas a síndrome autocórica (49\%), e em espécies trepadeiras uma proporção mais equilibrada entre as síndromes (38\% autocórica, 32\% anemocorica e 30\% zoocórica). A Floresta Nacional do Ibura apresentou níveis relativamente baixos de similaridade com outros sítios localizados na Mata Atlântica, possivelmente influênciados por isolamento e distância entre os fragmentos. Os resultados deste estudo indicam que a Floresta Nacional do Ibura é um refúgio de uma grande diversidade de espécies vegetais da Mata Atlântica, sendo uma área bastante heterogênea, que ainda é pouco estudada.
}

PALAVRAS CHAVES: Floresta Atlântica. Nordeste brasileiro. Diversidade. Flora. 


\section{REFERENCES}

ANDERSON, S. Area and endemism. Quarterly Review of Biology. n.69, p.451-471. 1994.

BRASIL. Decreto $\mathbf{n}^{\circ} \mathbf{9 . 9 8 5}$, de 19 de setembro de 2005 . Available in: <http://www.planalto.gov.br/ccivil_03/_Ato2004-2006/2005/Dnn/Dnn10637.htm>. Access in 15 de maio. 2013. https://doi.org/10.1086/418743.

FAHRIG, L. Effects of habitat fragmentation on biodiversity. Annual Review of Ecology, Evolution and Systematics. v. 34, p. 487-515. 2003. https://doi.org/10.1146/annurev.ecolsys.34.011802.132419

FERREIRA, E. V. R. Composição Florística, estrutura da comunidade e síndrome de dispersão de um remanescente de Caatinga em Poço Verde, Sergipe. Dissertação apresentado ao núcleo de Pós-Graduação em Ecologia e Conservação. Universidade Federal de Sergipe. São Cristovão. 2011.

FONSECA, M. R. Análise da vegetação arbustiva-árborea Caatinga Hiperxerófila do Nordeste do Estado de Sergipe. Tese apresentada a Pós-Graduação em Biologia Vegetaç do Instituto de Biologia da Universidade Estadual de Campinas. São Paulo. 2011.

FUNDAÇÃO SOS MATA ATLÂNTICA, INPE. Atlas dos remanescentes florestais da Mata Atlântica e ecossistemas associados no período de 1995-2000. Relatório final. São Paulo. 2002.

FUNDAÇÃO SOS MATA ATLÂNTICA, INPE. Atlas da evolução dos remanescentes florestais da Mata Atlântica e ecossistemas associados no período de 2012-2013. São Paulo. 2014.

GONÇALVES, E. G.; LORENZI, H. Morfologia vegetal: organografia e dicionário ilustrado de morfologia das plantas vasculares. Instituto Plantarum de Estudos da Flora, São Paulo. 2a ed. p. 512. 2011.

GROPPO, M.; ERBERT, C. Rutaceae. IN PRATA, A. P. N.; FARIS, M. C. V.; LANDIM, M. F. Flora de Sergipe. Aracaju. Editora Criação, v. 2, p. 300. 2015. ISBN 978-85-8413-050-4.

HAMMER, O.; HARPER, D. A. T.; RYAN, P. D. Past: Paleontological Statistics Software Package for Education and Data Analysis. Palaeontologia Electronica, v.4, n.1-9. 2001. Available at: http://palaeoelectronica.org/2001_1/past/issue1_01.htm.

MITTERMEIER, R. A.; GIL, P. R.; HOFFMANN, M.; PILGRIM, J.; BROOKS, T.; MITTERMEIER, C. G.; LAMOURUX, J.; FONSECA, G. A. B. Hotspots revisited: Earth's biologically richest and most endangered terrestrial ecoregions. Cemex. Washington, DC. 2004.

HOWE, H. F.; SMALLWOOD, J. Ecology of seed dispersal. Annual Review of Ecology and Systematics, v. 13: p. 201-228. 1982. https://doi.org/10.1146/annurev.es.13.110182.001221

NOGUEIRA-JÚNIOR, F. C. Estrutura e composição de uma vegetação ripária, relações dendrocronológicas e climáticas na serra dos Macacos em Tobias Barreto, Sergipe-Brasil. Dissertação apresentado ao núcleo de Pós-Graduação em Ecologia e Conservação. Universidade Federal de Sergipe. São Cristovão, 2011.

PRADO-JÚNIOR, J. A.; DO VALE, V. S.; DE FARIA LOPES, S.; DE SILVÉRIO ARANTES, C.; DE OLIVEIRA, A. P.; SCHIAVINI, I. Impacts of disturbance intensity in functional traits patterns in understories of seasonal forests. Bioscience Journal, Uberlândia, v. 5, p. 30. 2014.

LANDIM, M. F.; LANDRUM, L. R. The genus Campomanesia (Myrtaceae) in Atlantic rain forest fragments in Sergipe, Northeast region of Brazil. Sida, v. 20, n. 1, p. 205-214. 2002. 
LANDIM, M. F.; PROENÇA, C. E. B.; SALES, A. B.; MATOS, I. S. Floristic characterization of an Atlantic Rainforest remnant in Southern Sergipe: Crasto forest. Biota Neotropica v. 15, n. 1, p. 1-16. 2015. https://doi.org/10.1590/1676-06032014003613

LIST OF SPECIES OF THE BRAZILIAN FLORA. Rio de Janeiro Botanical Garden. Available in: $<$ http://floradobrasil.jbrj.gov.br/>. Accessed in 24 July 2015.

MACHADO, W. J.; PRATA, A. P. N.; MELLO, A. A. Floristic composition in areas of Caatinga and Brejo de Altitude in Sergipe state, Brazil. Check List. v. 8, n. 6, p. 1089-1101. 2012. https://doi.org/10.15560/8.6.1089

MARANGON, L. C.; SOARES, J. J.; FELICIANO, A. L. P. Florística arbórea da mata da pedreira, município de Viçosa, Minas Gerais. Minas Gerais. Revista árvore, v. 27, n. 2. 2003. https://doi.org/10.1590/S010067622003000200010

MARTINS-DA-SILVA, R. C. V.; SILVA, A. S. L.; FERNANDES, M. M.; MARGALHO, L. F. Noções morfológicas e taxonômicas para identificação botânica. Embrapa. Brasília, DF. p. 111. 2014.

MAURER, B. A. Geographical population analysis: Tools for the analysis of biodiversity. Oxford: Blackwell Scientific Pub. 1994.

MENDES, K.; GOMES, P.; ALVEZ, M. Floristic inventory of a zone of ecological tension in the Atlantic Forest of Northeastern Brazil. Rodriguésia. v. 61, n. 4, p. 669-676. 2010.

MOREIRA, A. L. C.; QUEIROZ, E. P.; PIGOZZO, C. M. Síndromes de dispersão de frutos e sementes do fragmento urbano (19 $\mathrm{BC}$ ) de Mata Atlântica, Cabula, Salvador, Bahia. Candombá. Revista Virtual, v. 5, n. 1, p. 13-25. 2009.

MOURA, F. B. P.; DUARTE, J. M. M.; LEMOS R. P. L. Floristic composition ande dispersal syndromes at na urban remanant from the Atlantic Forest in Brazilian Northeast. Acta Scientiarum. Biological Sciences Maringá, v. 33, n. 4, p. 471-478. 2011.

OLIVEIRA, D. G.; FERREIRA, R. A.; MELLO, A. A.; ALMEIDA, E. S. Estrutura diamétrica da vegetação arbustivo-arbórea no entorno de nascentes da bacia hidrográfica do rio Piauitinga, Salgado, SE, Brasil. Biotemas, v. 26, n. 2, p. 19-31, junho. 2013.

OLIVEIRA, E. V.; LANDIM, M. F. Caracterização fitofisionômica das restingas da Reserva Biológica de Santa Isabel, litoral norte de Sergipe. Scientia Plena, v. 10, n. 10. 2014.

OLIVEIRA, L. S. B.; MARANGON, L. C.; FELICIANO, A. L. P.; LIMA, A. S.; CARDOSO, M. O.; SILVA, V. F. Florística, classificação sucessional e síndromes de dispersão em um remanescente de Floresta Atlântica, Moreno-PE. Revista Brasileira de Ciências. Agrár., Recife, v. 6, n. 3, p. 502-507. 2011.

PINTO, L. P.; BEDÊ, L.; PAESE, A.; FONSECA, M.; PAGLIA, A.; LAMAS, I. Mata Atlântica Brasileira: os desafios para conservação da biodiversidade de um hotspot mundial. Biologia da Conservação: essências. RiMa, São Carlos, Brasil, p. 69-96. 2006.

PIZO, M. A.; SILVA, W. R., GALETTI, M.; LAPS, R. Frugivory in cotingas of the Atlantic Forest of southeast Brazil. Ararajuba, p. 177-185. 2002.

PRATA, A. P. N.; AMARAL, M. C. E.; FARIAS, M. C. V.; ALVES, M.; SILVA, A. C. C.; DÉDA, R. M.; SOUZA, C. A. S. Flora de Sergipe. In $64^{\circ}$ CONGRESSO NACIONAL DE BOTÂNICA. Anais. Belo Horizonte, p. 10-15 de novembro. 2013.

PRATA, A. P. N.; FARIAS, M. C. V.; LANDIM, M. F. Flora de Sergipe. Aracaju. Editora Criação, v. 2. p. 300. 2015. ISBN 978-85-8413-050-4. 
REYS, P.; GALETTI, M.; MORELlATO, L. P. C.; SABINO, J. Fenologia reprodutiva e disponibilidade de frutos de espécies arbóreas em mata ciliar no rio Formoso, Mato Grosso do Sul. Biota Neotropica, v. 5, n. 2, 309-318. 2005. https://doi.org/10.1590/S1676-06032005000300021

RIBAS, R. F.; MEIRA NETO, J. A. A.; SILVA, A. F.; SOUZA, A. L. Composição florística de dois trechos em diferentes etapas serais de uma Floresta Estacional Semidecidual em Viçosa, Minas Gerais. Revista Árvore, Viçosa, v. 27, n. 6, p. 821-830. 2003.

SANTOS, P. M. Composição florística e estrutura de habitat do Refúgio de Vida Silvestre Matam do Junco e de fragmentos próximos: Influência na presença de Callicebus coimbrai Kobayashi and Langguth, 1999. 57 pp. Undergraduate thesis. São Cristóvão: Universidade Federal de Sergipe. 2011.

SARAVY, F. D.; FREITAS, P. J.; LAGE, M. A.; LEITE, S. J.; BRAGA, L. F.; SOUSA, M. P. Síndrome de dispersão em estrato arbóreo em um fragmento de floresta Ombrófila Aberta e Densa em alta Floresta - MT. Revista do Programa de Ciências Agro-Ambientais, Alta Floresta, v. 2, n. 1, p. 1-12. 2003.

SILVA, A. C. C.; PRATA, A. P. N.; MELlO, A. A. Flowering plants of the Grota do Angico Natural Monument, Caatinga of Sergipe, Brazil. Check List., v. 9, n. 4, p. 733-739. 2013. https://doi.org/10.15560/9.4.733

SOUZA, B.; LANDIM, M. F. Unidades de conservação no estado de sergipe: análise do quadro atual. Caxambu - MG. In VIII CONGRESSO DE ECOLOGIA DO BRASIL. Anais. 23 a 28 de Setembro. 2007.

SOUZA-ALVES, J. P.; BARBOSA, M. R. V.; FERRARI, S. F.; THOMAS, W. M. W. Diversity of trees and lianas in two sites in the coastal Atlantic Forest of Sergipe, northeastern Brazil. Check List, v. 10, n. 4, p. 709717. 2014. https://doi.org/10.15560/10.4.709

STEHMANN, J. R.; FORZZA, R.; SALINO, A.; SOBRAL, M; COSTA, D.P.; KAMINO, L.H.Y. Plantas da Floresta Atlântica. Jardim Botânico do Rio de Janeiro, Rio de Janeiro, p. 516. 2009.

SUAREZ, S. A. Diet and Travel Costs for Spider Monkeys in a Nonseasonal, hyperdiverse environment. International Journal of Primatology, v. 27, n. 2, p. 411-436. 2006. https://doi.org/10.1007/s10764-0069023-6

TABARELli, M.; PINTO, L. P.; SILVA, J. M. C.; HIROTA, M. M.; BEDÊ, L. C. Desafios e oportunidades para a conservação da biodiversidade na Mata Atlântica brasileira. Megadiversidade. Belo Horizonte, v. 1, n. $1,2005$.

VAN DER PIJL, L. Principles of dispersal in higher plants. Berlin: Springer-Verlag. 3rd ed., p. 214. 1982. https://doi.org/10.1007/978-3-642-87925-8

VICENTE, A.; RIBEIRO, A. S.; SANTOS, E. A.; FRANCO, C. R. P. Levantamento botânico in: Parque Nacional Serra de Itabaiana - levantamento da biota (Carvalho, C. M.; Vilar, J. C. Coord.). Aracaju, Ibama, Biologia Geral e Experimental - UFS. p. 15-37. 2005. 


\section{[Appendix and Captions]}

Appendix 1 - List of families with the highest number of species in the Ibura National Forest, state of Sergipe. Legend: Habit $=$ Habitat, Epi $=$ epiphytic, Her $=$ herbaceous, Shr $=$ Shrub, Tre $=$ tree, Clim $=$ climber. Dispr $=$ Dispersal, Anem $=$ Anemochoric, Aut $=$ Autochoric, Zoo $=$ Zoochoric, Orig $=$ Origin, Natur $=$ Naturalized, Exot $=$ Exotic, End $=$ Endemic, M. Atla $=$ Atlantic Forest, M. Atla SE, Atlantic Forest Sergipe, Nord $=$ Northeast, Caat $=$ Caatinga, $V=$ Voucher $(A S E),(*)=$ new records for the Atlantic Forest of Sergipe, $(<>)=$ new taxon for the Atlantic Forest.

\begin{tabular}{|c|c|c|c|c|c|c|}
\hline Ferns & & & & & & \\
\hline Family/Species & Habitat & Dispr & Origin & End & $\begin{array}{l}\text { Collector/Number } \\
\text { (ASE) }\end{array}$ & V.(ASE) \\
\hline \multicolumn{7}{|l|}{ Lygodiaceae } \\
\hline Lygodium venustum $\mathrm{Sw}$. & Her & Anem & Native & - & T.R.Silva 68 & 27050 \\
\hline \multicolumn{7}{|l|}{ Polypodiaceae } \\
\hline Serpocaulon sp.* & Her & Anem & Native & - & J.P.Santana 152 & 30730 \\
\hline \multicolumn{7}{|l|}{ Pteridaceae } \\
\hline Vittaria lineata (L.) Sw.* & Epi & Ane & Native & - & J.P.Santana 469 & 36289 \\
\hline \multicolumn{7}{|l|}{ Gymnosperm } \\
\hline Family/Species & Habitat & Dispr & Origin & End & $\begin{array}{l}\text { Collector/Number } \\
\text { (ASE) }\end{array}$ & V.(ASE) \\
\hline \multicolumn{7}{|l|}{ Pinaceae } \\
\hline Pinus caribaea Morelet & Tre & Anem & Exot & - & G.Viana 3576 & 3576 \\
\hline \multicolumn{7}{|l|}{ Angiosperms } \\
\hline Family/Species & Habitat & Dispr & Origin & End & $\begin{array}{l}\text { Collector/Number } \\
\text { (ASE) }\end{array}$ & V.(ASE) \\
\hline \multicolumn{7}{|l|}{ Acanthaceae } \\
\hline Dieliptera $s p$ & Her & - & Native & - & J.P. Santana 99 & 29965 \\
\hline Ruellia bahiensis (Nees) Morong* & Her & Aut & Native & - & J.P.S.Santos 82 & 29655 \\
\hline Ruellia ochroleuca Mart. ex Nees* & Her & Aut & Native & - & T.R.Silva 04 & 25281 \\
\hline Ruellia humilis Nutt. & Her & Aut & Native & - & J.P.S.Santos 20 & 26122 \\
\hline Sanchezia sp & Her & Aut & - & - & J.P.S.Santos 03 & 26097 \\
\hline Thunbergia alata Bojer ex Sims* & Her & Aut & Natur & & G.S.Freire 03 & 25288 \\
\hline \multicolumn{7}{|l|}{ Aizoaceae } \\
\hline Sesuvium portulacastrum L. & Her & - & Native & - & J.P.S.Santos 75 & 29389 \\
\hline \multicolumn{7}{|l|}{ Alstroemeriaceae } \\
\hline Bomarea edulis (Tussac) Herb. & Clim & - & Native & - & J.P.Santana 107 & 29973 \\
\hline \multicolumn{7}{|l|}{ Amaranthaceae } \\
\hline Alternanthera tenella Colla & Her & - & Native & - & J.P.Santana 85 & 29658 \\
\hline Eucharis sp.* & Her & - & Natur & - & J.P.Santana 118 & 29984 \\
\hline \multicolumn{7}{|l|}{ Anacardiaceae } \\
\hline Schinus terebinthifolius Raddi & Shr & Zooc & Native & - & T.R.Silva 106 & 27630 \\
\hline Spondias mombin L. & Shr & Zooc & Native & - & J.P.Santana 170 & 30748 \\
\hline Tapirira guianensis Aubl. & Tre & Zooc & Native & - & T.R.Silva 128 & 28213 \\
\hline \multicolumn{7}{|l|}{ Angeloniaceae } \\
\hline Angelonia biflora Benth.* & Her & - & Native & - & T.R.Silva 126 & 28211 \\
\hline \multicolumn{7}{|l|}{ Annonaceae } \\
\hline Annona montana Macfad* & Shr & Zooc & Native & - & T.R.Silva 118 & 27642 \\
\hline Duguetia gardneriana Mart. & Shr & Zooc & Native & - & J.P.S.Santos 11 & 26105 \\
\hline \multicolumn{7}{|l|}{ Apocynaceae } \\
\hline Allamanda cathartica $\mathrm{L}$ & Her & Aut & Native & - & J.P.S.Santos 38 & 26142 \\
\hline Cryptostegia grandiflora Roxb. & Clim & Ane & Natur & - & J.P.Santana 64 & 29053 \\
\hline Himatanthus obovatus (Müll. Arg.) Woodson & Tre & Ane & Native & - & T.R.Silva 58 & 26994 \\
\hline Mandevilla hirsuta (Rich.) K. Schum. & Clim & Ane & Native & - & E.M.Carneiro 92 & 1446 \\
\hline $\begin{array}{l}\text { Mandevilla scabra (Hoffmanns. ex Roem. \& } \\
\text { Schult.) K. Schum. }\end{array}$ & Clim & Ane & Native & - & J.P.S.Santos 07 & 26101 \\
\hline Matelea ganglinosa (Vell.) Rapini & Clim & Ane & Native & - & J.P.Santana 81 & 29654 \\
\hline Rauvolfia ligustrina Willd. ex Roem. \& Schult. & Shr & Ane & Native & - & J.P.Santana 80 & 29653 \\
\hline Tabernaemontana $s p$. & Shr & Ane & Native & - & T.R.Silva 56 & 26992 \\
\hline Temnadenia violacea (Vell.) Miers & Clim & Ane & Native & - & T.R.Silva 127 & 28212 \\
\hline \multicolumn{7}{|l|}{ Araceae } \\
\hline Anthurium sp. & Her & Zooc & Native & - & T.R.Silva 124 & 28209 \\
\hline Caladium bicolor (Aiton) Vent.* & Her & Zooc & Native & - & J.P.Santana 63 & 29051 \\
\hline Spathicarpa sp.* & Her & Zooc & Native & - & T.R.Silva 148 & 29055 \\
\hline
\end{tabular}




\begin{tabular}{|c|c|c|c|c|c|c|}
\hline Syngonium vellozianum Schott* & Clim & Zooc & Native & - & T.R.Silva 115 & 27639 \\
\hline \multicolumn{7}{|l|}{ Araliaceae } \\
\hline $\begin{array}{l}\text { Scheffera morototoni (Aubl.) Maguire, Steyerm. } \\
\text { \& Frodin }\end{array}$ & Tre & Zooc & Native & - & J.P.Santana 607 & 37730 \\
\hline \multicolumn{7}{|l|}{ Arecaceae } \\
\hline Allagoptera caudescens (Mart.) Kuntze & Tre & Zooc & Native & - & J.P.Santana 283 & 33414 \\
\hline Cocos nucifera $\mathrm{L}$. & Tre & Zooc & Native & - & - & - \\
\hline Elaeis guineensis Jacq. & Tre & Zooc & Natur & - & - & - \\
\hline Syagrus coronata (Mart.) Becc. & Shr & Zooc & Native & - & J.P.Santana 287 & 33418 \\
\hline Zomicarpa pythonium (Mart.) Schott & Her & Zooc & Native & - & - & - \\
\hline \multicolumn{7}{|l|}{ Aristolochiaceae } \\
\hline Aristolochia birostris Duch. & Clim & - & Native & - & J.P.S.Santos 32 & 26135 \\
\hline \multicolumn{7}{|l|}{ Asteraceae } \\
\hline Albertinia brasiliensis Spreng. & Shr & Ane & Native & - & T.R.Silva 136 & 28428 \\
\hline Centratherum punctatum Cass. & Her & Ane & Native & - & G.S.Freire 06 & 25291 \\
\hline Eclipta prostrata (L.) L. & Her & Ane & Native & - & J.P.Santana 70 & 29378 \\
\hline Emilia sonchifolia (L.) DC. ex Wight & Her & Ane & Native & - & J.P.Santana 132 & 30606 \\
\hline Galinsoga quadriradiata Ruiz \& Pav.* & Her & Ane & Native & - & J.P.Santana 265 & 32568 \\
\hline Melanthera latifolia (Gardner) Cabrera & Her & Ane & Native & - & T.R.Silva 110 & 27634 \\
\hline Mikania sp. & Clim & Ane & Native & - & J.P.Santana 86 & 29390 \\
\hline Porophyllum ruderale (Jacq.) Cass.* & Her & Ane & Native & - & J.P.Santana 131 & 30605 \\
\hline Pterocaulon virgatum $(\mathrm{L}$.$) DC. *$ & Her & Ane & Native & - & T.R.Silva 120 & 28205 \\
\hline Sphagneticola trilobata (L.) Pruski. & Her & Ane & Native & - & J.P.S.Santos 01 & 26092 \\
\hline Tilesia baccata $(\mathrm{L}$.$) Pruski$ & Her & Zooc & Natur & - & J.P.Santana 51 & 29038 \\
\hline Tridax procumbens $\mathrm{L} . *$ & Her & Ane & Native & - & T.R.Silva 91 & 27376 \\
\hline Verbesina macrophylla (Cass.) S.F. Blake* & Her & Ane & Native & - & T.R.Silva, 157 & 29387 \\
\hline Vernonanthura sp. & Shr & Ane & Native & - & J.P.S.Santos 02 & 26095 \\
\hline \multicolumn{7}{|l|}{ Bignoniaceae } \\
\hline Bignonia corymbosa (Vent.) L.G.Lohmann & Clim & Ane & Native & & J.P.Santana 273 & 33404 \\
\hline Fridericia conjugata (Vell.) L.G.Lohmann* & Clim & Ane & Native & & J.P.Santana 274 & 33405 \\
\hline Handroanthus vellosoi (Toledo) Mattos.* & Tre & Ane & Native & M. Atla & T.R.Silva 85 & 27370 \\
\hline Lundia corymbifera (Vahl) Sandwith* & Clim & Ane & Native & - & J.P.S.Santos 25 & 26127 \\
\hline Tecoma stans (L.) Juss. ex Kunth. & Shr & Ane & Natur & - & - & \\
\hline \multicolumn{7}{|l|}{ Boraginaceae } \\
\hline Cordia pilosa M.Stapf \& Taroda & Her & Zooc & Native & M. Atla & T.R.Silva 114 & 27638 \\
\hline Cordia superba Cham. & Shr & Zooc & Native & - & J.P.Santana 110 & 29976 \\
\hline Cordia taguahyensis Vell. & Her & Zooc & Native & - & J.P.S.Santos 40 & 28435 \\
\hline Cordia toqueve Aubl. & Tre & Zooc & Native & - & T.R.Silva 152 & 29060 \\
\hline Myriopus rubicundus (Salzm. ex DC.) Luebert* & Her & Zooc & Native & - & J.P.Santana 113 & 29979 \\
\hline Myriopus salzmannii (DC.) Diane \& Hilger* & Her & Zooc & Native & - & J.P.Santana 172 & 30838 \\
\hline Varronia curassavica Jacq. & Shr & Zooc & Native & - & T.R.Silva 65 & 27001 \\
\hline Varronia globosa Jacq.* & Shr & Zooc & Native & - & J.P.Santana 111 & 29977 \\
\hline \multicolumn{7}{|l|}{ Burseraceae } \\
\hline Protium heptaphyllum (Aublet) Marchand & Tre & Zooc & Native & - & J.P.Santana 149 & 30727 \\
\hline \multicolumn{7}{|l|}{ Cactaceae } \\
\hline Epiphyllum phyllanthus $\mathrm{L}$. & Epi & Zooc & Native & - & T.R.Silva 146 & 29052 \\
\hline \multicolumn{7}{|l|}{ Cannabaceae } \\
\hline Celtis iguanaea (Jacq.) Sarg. & Shr & Zooc & Native & - & T.R.Silva 99 & 27622 \\
\hline Trema micrantha $(\mathrm{L}$.$) Blume$ & Shr & Zooc & Native & - & T.R.Silva 159 & 30847 \\
\hline \multicolumn{7}{|l|}{ Cannaceae } \\
\hline Canna paniculata Ruiz \& Pav. & Her & Aut & Native & - & J.P.Santana 79 & 29652 \\
\hline \multicolumn{7}{|l|}{ Capparaceae } \\
\hline Cynophalla flexuosa (L.) J. Presl & Tre & Zooc & Native & - & J.P.Santana 71 & 11093 \\
\hline Hemiscola aculeata (L.) Raf. & Shr & Zooc & Native & - & J.P.Santana 117 & 29983 \\
\hline \multicolumn{7}{|l|}{ Chrysobalanaceae } \\
\hline Hirtella racemosa Lam. & Shr & Zooc & Native & - & T.R.Silva 70 & 27052 \\
\hline Licania rigida Benth.* & Tre & Zooc & Native & - & T.R.Silva 64 & 27000 \\
\hline Licania tomentosa (Benth.) Fritsch* & Tre & Zooc & Native & M. Atla & T.R.Silva 63 & 26999 \\
\hline \multicolumn{7}{|l|}{ Clusiaceae } \\
\hline Clusia nemorosa G.Mey. & Tre & Zooc & Native & - & T.R.Silva 117 & 27641 \\
\hline \multicolumn{7}{|l|}{ Combretaceae } \\
\hline Conocarpus erectus $\mathrm{L}$. & Tre & Ane & Native & - & T.R.Silva 111 & 27635 \\
\hline Laguncularia racemosa $\mathrm{L}$. & Tre & Hidr & Native & - & T.R.Silva 107 & 27631 \\
\hline Commelinaceae & & & & & & \\
\hline
\end{tabular}




\begin{tabular}{|c|c|c|c|c|c|c|}
\hline Commelina erecta $\mathrm{L}$. & Her & Aut & Native & - & T.R.Silva 138 & 28430 \\
\hline Commelina benghalensis $\mathrm{L}$. & Her & Aut & Native & - & J.P.S.Santos 18 & 26120 \\
\hline $\begin{array}{l}\text { Dichorisandra hexandra (Aubl.) Kuntze ex } \\
\text { Hand.-Mazz. }\end{array}$ & Her & Aut & Native & - & J.P.Santana 254 & 32657 \\
\hline \multicolumn{7}{|l|}{ Convolvulaceae } \\
\hline Evolvulus nummularius (L.) L.* & Clim & Ane & Native & - & J.P.Santana 74 & 29385 \\
\hline Ipomoea bahiensis Willd. ex Roem. \& Schult. & Clim & Ane & Native & - & J.P.Santana 119 & 30593 \\
\hline Ipomoea nil (L.) Roth & Clim & Ane & Natur & - & T.R.Silva 11 & 25304 \\
\hline Ipomoea eriocalyx Meisn & Clim & Ane & Native & - & T.R.Silva 17 & 26109 \\
\hline Ipomoea indica (Burmi. f.) Merr. & Clim & Ane & Native & - & T.R.Silva 44 & 25451 \\
\hline Jacquemotia blanchetii Moric. & Clim & Aut & Native & & J.P.Santana 272 & 33403 \\
\hline Merremia cissoides (Lam.) Hallier f. & Clim & Aut & Native & - & J.P.Santana 258 & 32561 \\
\hline Merremia macrocalyx (Ruiz et Pavon) O'Donell. & Clim & Aut & Native & - & J.P.S.Santos 04 & 26098 \\
\hline \multicolumn{7}{|l|}{ Costaceae } \\
\hline Costus spicatus (Jacq.) Sw. & Shr & Zooc & Natur & - & J.P.S.Santos 31 & 26134 \\
\hline \multicolumn{7}{|l|}{ Cucurbitaceae } \\
\hline Cayaponia tayuya (Vell.) Cogn.* & Clim & Zooc & Native & - & GAGC 307 & 27046 \\
\hline Melothria pendula $\mathrm{L}$. & Clim & Zooc & Native & - & J.P.Santana 168 & 30746 \\
\hline Momordica charantia $\mathrm{L}$. & Clim & Zooc & Natur & - & T.R.Silva 46 & 25453 \\
\hline \multicolumn{7}{|l|}{ Cyperaceae } \\
\hline Cyperus ligularis $\mathrm{L}$. & Her & Ane & Native & - & T.R.Silva 98 & 27621 \\
\hline Eleocharis sp. & Her & Ane & Native & - & J.P.Santana 184 & 32291 \\
\hline Fimbristylis dichotoma $(\mathrm{L}$.$) Vahl$ & Her & Ane & Native & - & J.P.Santana 185 & 32292 \\
\hline Kyllinga brevifolia Rottb. & Her & Ane & Native & - & T.R.Silva 142 & 28434 \\
\hline Kyllinga odorata Vahl & Her & Ane & Native & - & T.R.Silva 154 & 29382 \\
\hline Rhynchospora cephalotes (L.) Vahl & Her & Ane & Native & - & J.P.Santana 166 & 30744 \\
\hline Scleria gaertneri Raddi & Her & Ane & Native & - & T.R.Silva 135 & 28427 \\
\hline Scleria sp. & Her & Ane & Native & - & J.P.Santana 186 & 32293 \\
\hline \multicolumn{7}{|l|}{ Dioscoreaceae } \\
\hline Dioscorea piperifolia Humb \& Bonpl. ex Willd. & Her & Ane & Native & - & J.P.Santana 77 & 29650 \\
\hline Dioscorea subhastata Vell. & Her & Ane & Native & - & J.P.Santana 253 & 32656 \\
\hline \multicolumn{7}{|l|}{ Ebenaceae } \\
\hline Diospyros inconstans Jacq.* & Shr & Zooc & Native & - & J.P.Santana 269 & 33400 \\
\hline \multicolumn{7}{|l|}{ Eriocaulaceae } \\
\hline Paepalanthus myocephalus (Mart.) Körn. & Her & Ane & Native & Nord & J.P.Santana 169 & 30747 \\
\hline \multicolumn{7}{|l|}{ Erythroxylaceae } \\
\hline Erythroxylum citrifolium A. St. - Hil & Shr & Zooc & Native & - & J.P.Santana 260 & 32563 \\
\hline Erythroxylum subrotundum A.St. Hil & Shr & Zooc & Native & - & J.P.Santana 340 & 34809 \\
\hline Erythroxylum $s p$ & Shr & Zooc & Native & - & J.P.Santana 332 & 34802 \\
\hline Erythroxylum passerinum Mart. & Shr & Zooc & Native & - & J.P.Santana 392 & 35131 \\
\hline \multicolumn{7}{|l|}{ Euphorbiaceae } \\
\hline Actinostemon verticillatus (Klotsch) Baill & Shr & Zooc & Native & M. Atla & J.P.Santana 182 & 30850 \\
\hline Aleurites moluccanus (L.) Willd. & Shr & Zooc & native & & T.R.Silva 108 & 27632 \\
\hline Croton fuscescens Spreng. & Her & Zooc & Native & - & G.D.Freire 08 & 25293 \\
\hline Croton glandulosus $\mathrm{L}$. & Her & Aut & Native & - & T.R.Silva 144 & 29037 \\
\hline Croton hirtusL'Her & Her & Aut & Native & - & J.P.Santana 54 & 29041 \\
\hline Croton triqueter Lam. & Her & Zooc & Native & - & T.R.Silva 137 & 28429 \\
\hline Croton heliotropiifolius Kunth. & Her & Zooc & Native & - & T.R.Silva 15 & 26096 \\
\hline Dalechampia brasiliensis Lam.* & Clim & Aut & Native & - & J.P.Santana 181 & 30849 \\
\hline Dalechampia peckoltiana Mull. Arg. & Clim & Aut & Native & - & J.P.Santana 347 & 34817 \\
\hline Euphorbia hirta Millsp & Her & Aut & Native & - & J.P.Santana 126 & 30600 \\
\hline Microstachys corniculata (Vahl) Griseb. & Her & Aut & Native & - & J.P.Santana 175 & 30841 \\
\hline Sapium glandulosum (L.) Morong & Shr & Zooc & Native & - & T.R.Silva 123 & 28208 \\
\hline Tragia volubilis L.* & Clim & Aut & Native & - & T.R.Silva 74 & 27056 \\
\hline \multicolumn{7}{|l|}{ Fabaceae } \\
\hline Aeschynomene marginata Benth. & Tre & - & Native & - & J.P.Santana 67 & 29049 \\
\hline Andira nitida Mart. ex Benth. & Tre & Zooc & Native & M. Atla & T.R.Silva 113 & 27637 \\
\hline Bauhinia forficata Link.* & Shr & Aut & Native & - & T.R.Silva 34 & 25441 \\
\hline Bowdichia virgilioides Kunth. & Tre & Ane & Native & - & J.P.S.Santos 22 & 26124 \\
\hline Caesalpinia echinata Lam.* & Shr & Aut & Native & M. Atla & T.R.Silva 97 & 27620 \\
\hline Calopogonium mисunoides Desv. & Clim & Aut & Native & - & J.P.Santana 139 & 30717 \\
\hline Canavalia brasiliensis Mart. ex Benth. & Clim & Aut & Native & - & J.P.Santana 139 & 30721 \\
\hline Cassia grandis L. f. & Tre & Aut & Native & - & J.P.S.Santos 23 & 26125 \\
\hline Centrosema brasilianum (L.) Benth. & Clim & Aut & Native & - & J.P.S.Santos 33 & 30725 \\
\hline
\end{tabular}




\begin{tabular}{|c|c|c|c|c|c|c|}
\hline $\begin{array}{l}\text { Centrosema sagittatum (Humb. \& Bonpl. ex } \\
\text { Willd.) Brandegee* }\end{array}$ & Clim & Aut & Native & - & J.P.Santana 147 & 26136 \\
\hline Chamaecrista desvauxii (Collad.) Killip & Her & Aut & Native & - & J.P.Santana 68 & 29376 \\
\hline $\begin{array}{l}\text { Chamaecrista ensiformis (Vell.) H.S.Irwin } \\
\text { \&Barneby }\end{array}$ & Tre & Aut & Native & - & T.R.Silva 122 & 28207 \\
\hline $\begin{array}{l}\text { Chamaecrista hispidula (Vahl) H.S. Irwin \& } \\
\text { Barneby }\end{array}$ & Her & Aut & Native & - & J.P.S.Santos 42 & 28437 \\
\hline Chamaecrista nictitans (L.) Moench & Her & Aut & Native & - & J.P.Santana 148 & 30726 \\
\hline Clitoria fairchildiana R.A. Howard & Tre & Aut & Native & - & T.R.Silva 55 & 26991 \\
\hline Crotalaria spectabilis Roth & Her & Aut & Natur & - & T.R.Silva 01 & 25278 \\
\hline Dalbergia sp. & Tre & Aut & Native & - & T.R.Silva 133 & 28218 \\
\hline Desmodium incanum DC. & Her & Epiz & Natur & - & T.R.Silva 57 & 26993 \\
\hline Dioclea $s p$ & Shr & Aut & Native & - & T.R.Silva 89 & 27374 \\
\hline Dioclea virgata (Rich.) Amshoff. & Shr & Aut & Native & - & J.P.S.Santos 15 & 26114 \\
\hline Enterolobium contortisiliquum (Vell.) Morong.* & Tre & Zooc & Native & - & J.P.S.Santos 30 & 26133 \\
\hline Inga capitata Desv. & Tre & Zooc & Native & - & J.P.Santana 174 & 30840 \\
\hline Inga cayennensis Sagot ex Benth. & Tre & Zooc & Native & - & T.R.Silva 77 & 27059 \\
\hline Inga laurina $(\mathrm{Sw}$.$) Willd.*$ & Tre & Zooc & Native & - & T.R.Silva 51 & 26987 \\
\hline Leucaena leucocephala (Lam.) de Wit & Shr & Aut & Natur & - & T.R.Silva 84 & 27369 \\
\hline Lonchocarpus sericeus (Poir.) Kunth ex DC.* & Shr & Aut & Native & - & J.P.Santana 134 & 30608 \\
\hline Machaerium hirtum (Vell.) Stellfeld & Tre & Ane & Native & & J.P.Santana 265 & 33396 \\
\hline Mimosa pudica $\mathrm{L} . *$ & Her & Aut & Native & - & T.R.Silva 79 & 27061 \\
\hline Mimosa arenosa (Willd.) Poir. & Shr & Aut & Native & - & E.M.Carneiro 154 & 1635 \\
\hline Mimosa tenuiflora (Willd.) Poir. & Shr & Aut & Native & - & J.P.S.Santos 24 & 26126 \\
\hline Pithecellobium dulce (Roxb.) Benth. & Tre & Zooc & Natur & - & & - \\
\hline Platypodium elegans Vogel* & Tre & Ane & Native & - & J.P.Santana 53 & 29040 \\
\hline Rhynchosia minima (L.) DC.* & Clim & Aut & Native & - & T.R.Silva 66 & 27048 \\
\hline Rhynchosia phaseoloides (Sw.) DC.* & Clim & Aut & Native & - & T.R.Silva 73 & 27055 \\
\hline $\begin{array}{l}\text { Senegalia giganticarpa (G.P.Lewis) Seigler \& } \\
\text { Ebinger* }\end{array}$ & Tre & Aut & Native & M. Atla & J.P.Santana 173 & 30839 \\
\hline $\begin{array}{l}\text { Senna cana (Nees \& C. Mart.) H. S. Irwin \& } \\
\text { Barneby. }\end{array}$ & Shr & Zooc & Native & - & T.R.Silva 36 & 25443 \\
\hline $\begin{array}{l}\text { Senna macranthera (DC. ex Collad.) H.S. Irwin \& } \\
\text { Barneby }\end{array}$ & Shr & Zooc & Native & - & J.P.S.Santos 50 & 28445 \\
\hline Senna georgica H.S.Irwin \& Barneby* & Arb & Zooc & Native & - & J.P.S.Santos 09 & 26103 \\
\hline Senna obtusifolia (L.) H.S. Irwin \& Barneby & Arb & Zooc & Native & - & T.R.Silva 05 & 25282 \\
\hline Stylosanthes viscosa (L.) Sw. & Her & Aut & Native & - & J.P.Santana 129 & 30603 \\
\hline Swartzia acutifolia Vogel* & Tre & Zooc & Native & & T.R.Silva 02 & 25279 \\
\hline Swartzia dipetala Willd. ex Vogel* & Shr & Zooc & Native & M. Atla & J.P.Santana 146 & 30724 \\
\hline Vigna sp.* & Clim & Aut & Native & - & J.P.Santana 140 & 30718 \\
\hline Zornia latifolia $\mathrm{Sm}$. & Her & Aut & Native & - & J.P.Santana 122 & 30596 \\
\hline \multicolumn{7}{|l|}{ Gentianaceae } \\
\hline Coutoubea spicata Aubl. & Her & Ane & Native & - & J.P.Santana 249 & 32652 \\
\hline Schultesia guianensis (Aubl.) Malme & Epi & Aut & Native & - & J.P.Santana 275 & 33406 \\
\hline \multicolumn{7}{|l|}{ Gesneriaceae } \\
\hline Codonanthe mattos-silvae Chautens. & Epi & Zooc & Native & & J.P.Santana 133 & 30607 \\
\hline Drymonia serrulata (Jacq.) Mart.* & Epi & Zooc & Native & M. Atla & T.R.Silva 121 & 28206 \\
\hline \multicolumn{7}{|l|}{ Heliconiaceae } \\
\hline Heliconia psittacorumL. & Epi & Zooc & Native & - & G.S.Freire 05 & 25290 \\
\hline \multicolumn{7}{|l|}{ Hypericaceae } \\
\hline Vismia guianensis (Aubl.) Pers. & Shr & Zooc & Native & - & T.R.Silva 62 & 26998 \\
\hline \multicolumn{7}{|l|}{ Hypoxidaceae } \\
\hline Hypoxis decumbens $\mathrm{L}$. & Her & Aut & Native & - & J.P.Santana 58 & 29046 \\
\hline \multicolumn{7}{|l|}{ Iridaceae } \\
\hline Cipura paludosa Aubl. & Her & Aut & Native & - & T.R.Silva 03 & 25280 \\
\hline \multicolumn{7}{|l|}{ Lamiaceae } \\
\hline Aegiphila vitelliniflora Walp.* & Shr & Zooc & Native & - & J.P.Santana 151 & 30729 \\
\hline Ocimum gratissimum $\mathrm{L}$. & Her & Aut & Natur & - & J.P.S.Santos 45 & 28440 \\
\hline Vitex rufescens A.Juss. & Her & Aut & Native & - & T.R.Silva 81 & 27063 \\
\hline \multicolumn{7}{|l|}{ Lauraceae } \\
\hline Ocotea glomerata (Nees) Mez & Tre & Aut & Native & - & J.P.Santana 155 & 30733 \\
\hline \multicolumn{7}{|l|}{ Lecythidaceae } \\
\hline Couroupita guianensis Aubl.* & Tre & Aut & Native & - & - & - \\
\hline Eschweilera ovata (Cambess.) Miers. & Tre & Zooc & Native & & T.R.Silva 104 & 27627 \\
\hline
\end{tabular}




\begin{tabular}{|c|c|c|c|c|c|c|}
\hline Eschweilera sp & Tre & Zooc & Native & - & T.R.Silva 32 & 26150 \\
\hline \multicolumn{7}{|l|}{ Loganiaceae } \\
\hline Spigelia anthelmia $\mathrm{L}$. & Her & Epiz & Native & - & J.P.Santana 145 & 30723 \\
\hline \multicolumn{7}{|l|}{ Lythraceae } \\
\hline Cuphea aperta Koehne. & Her & Aut & Native & - & J.P.S.Santos 48 & 28443 \\
\hline Cuphea carthagenensis (Jacq.) J.F.Macbr.* & Her & Aut & Native & - & J.P.S.Santos 14 & 30722 \\
\hline Cuphea racemosa (L. f.) Spreng. & Her & Aut & Native & - & J.P.Santana 144 & 29980 \\
\hline Cuphea sp. & Her & Aut & Native & - & J.P.Santana 114 & 26112 \\
\hline \multicolumn{7}{|l|}{ Malpighiaceae } \\
\hline Byrsonima sericea DC. & Tre & Zooc & Native & - & T.R.Silva 155 & 29383 \\
\hline Stigmaphyllon blanchetii C.E. Anderson & Clim & Ane & Native & - & J.P.S.Santos 17 & 25285 \\
\hline \multicolumn{7}{|l|}{ Malvaceae } \\
\hline Abutilon ramiflorum A.St.-Hil.* & Her & Aut & Native & - & J.P.Santana 150 & 30728 \\
\hline Apeiba tibourbou Aubl. & Shr & Zooc & Native & - & T.R.Silva 41 & 25448 \\
\hline Corchorus hirtus L. & Her & Aut & Native & - & J.P.Santana 125 & 30599 \\
\hline Guazuma ulmifolia Lam. & Shr & Zooc & Native & - & T.R.Silva 82 & 25295 \\
\hline Pavonia cancellata (L.) Cav. & Clim & Aut & Native & - & T.R.Silva 37 & 25444 \\
\hline Sida ciliares Small & Her & Aut & native & & J.P.Santana 104 & 29970 \\
\hline Sida linifolia Cav. & Her & Aut & Native & - & J.P.Santana 128 & 30602 \\
\hline Sida spinosa L.* & Her & Aut & Native & - & J.P.Santana 127 & 30601 \\
\hline Triumfetta semitriloba Jacq* & Her & Epiz & Native & - & J.P.Santana 130 & 30604 \\
\hline Waltheria viscosissima A. St.-Hil. & Her & Aut & Native & - & T.R.Silva 71 & 27053 \\
\hline Waltheria indica $\mathrm{L}$. & Her & Aut & Native & - & T.R.Silva 92 & 27377 \\
\hline \multicolumn{7}{|l|}{ Marantaceae } \\
\hline $\begin{array}{l}\text { Goeppertia villosa (Lodd. ex Sweet) Borchs. \& S. } \\
\text { Suárez }\end{array}$ & Her & - & Native & - & J.P.Santana 153 & 30731 \\
\hline Maranta noctiflora Regel \& Korn. & Her & Aut & Native & M. Atla & J.P.Santana 100 & 29966 \\
\hline \multicolumn{7}{|l|}{ Melastomataceae } \\
\hline Aciotis $s p{ }^{*}$ & Her & Zooc & Native & - & J.P.Santana 177 & 29656 \\
\hline Clidemia hirta (L.) D. Don & Her & Zooc & Native & - & J.P.Santana 338 & 25292 \\
\hline Miconia albicans (Sw.) Triana & Shr & Zooc & Native & - & J.P.Santana 333 & 34803 \\
\hline \multicolumn{7}{|l|}{ Meliaceae } \\
\hline Guarea guidonia (L.) Sleumer & Tre & Zooc & Native & - & J.P.Santana 142 & 30720 \\
\hline \multicolumn{7}{|l|}{ Menispermaceae } \\
\hline Cissampelos glaberrima A. St.-Hil.* & Clim & Zooc & Native & - & T.R.Silva 160 & 30848 \\
\hline Cissampelos sympodialis Eichler & Clim & Zooc & Native & - & J.P.Santana 263 & 32566 \\
\hline Hyperbaena sp. & Clim & - & Native & - & J.P.Santana 264 & 32567 \\
\hline \multicolumn{7}{|l|}{ Moraceae } \\
\hline Artocarpus heterophyllus Lam. & Tre & Zooc & Natur & - & T.R.Silva 40 & 25447 \\
\hline Maclura tinctoria (L.) D.Don ex Steud.* & Tre & Zooc & Native & - & T.R.Silva 130 & 28215 \\
\hline Sorocea hilarii Gaudich.* & Tre & Zooc & Native & - & J.P.Santana 266 & 33397 \\
\hline \multicolumn{7}{|l|}{ Myrtaceae } \\
\hline Campomanesia aromatica (Aubl.) Griseb. & Shr & Zooc & Native & - & J.P.Santana 326 & 34796 \\
\hline Campomanesia dichotoma (O.Berg) Mattos & Tre & Zooc & Native & - & J.P.Santana 555 & $37676 \mathrm{~A}$ \\
\hline Campomanesia ilhoensis Mattos & Shr & Zooc & Native & Nord & J.P.Santana 154 & 30732 \\
\hline Eugenia aff. punicifolia Kunth. & Tre & Zooc & Native & - & Gage 305 & 27628 \\
\hline Eugenia astringens Cambess. & Shr & Zooc & Native & M. Atla & J.P.Santana 259 & 32562 \\
\hline Eugenia brejoensis Mazine & Tre & Zooc & Native & M. Atla & J.P.Santana 247 & 32650 \\
\hline Eugenia hirta O. Berg & Shr & Zooc & Native & M. Atla & J.P.Santana 156 & 30734 \\
\hline Eugenia schottiana O. Berg & Shr & Zooc & Native & - & J.P.Santana 261 & 32564 \\
\hline Eugenia sp. & Shr & Zooc & Native & - & J.P.Santana 141 & 30719 \\
\hline Marlierea excoriata Mart. & Shr & Zooc & Native & - & J.P.Santana 255 & 32658 \\
\hline Myrcia splendens (Sw.) DC. & Shr & Zooc & Native & - & J.P.Santana 268 & 27372 \\
\hline Myrcia tomentosa (Aubl.) DC. & Shr & Zoocc & Native & - & J.P.Santana 436 & 36570 \\
\hline Myrciaria floribunda (West. ex Willd.) O. Berg & Shr & Zooc & Native & - & J.P.Santana 251 & 32654 \\
\hline Psidium decussatum DC. & Tre & Zooc & Native & - & J.P.Santana 157 & 30735 \\
\hline Psidium guineense $\mathrm{Sw}$. & Shr & Zooc & Native & - & T.R.Silva 72 & 27054 \\
\hline Psidium $s p$ & Shr & Zooc & Native & - & J.P.Santana 288 & 33419 \\
\hline Psidium guajava $\mathrm{L}$. & Shr & Zooc & Native & - & T.R.Silva 38 & 25445 \\
\hline Syzygium cumini (L.) Skeels & Tre & Zooc & Natur & - & T.R.Silva 59 & 26995 \\
\hline \multicolumn{7}{|l|}{ Nyctaginaceae } \\
\hline Bougainvillea spectabilis Willd.* & Shr & Ane & Native & - & T.R.Silva 103 & 27626 \\
\hline \multicolumn{7}{|l|}{ Nymphaeaceae } \\
\hline Nymphaea pulchella DC. & Her & Hidr & Native & - & J.P.Santana 163 & 30741 \\
\hline
\end{tabular}




\begin{tabular}{|c|c|c|c|c|c|c|}
\hline Onagraceae & & & & & & \\
\hline Ludwigia octovalvis (Jacq.) & Her & Aut & Native & - & J.P.Santana 256 & 32659 \\
\hline \multicolumn{7}{|l|}{ Orchidaceae } \\
\hline Alatiglossum barbatum (Lindl.) & Her & Ane & Native & - & J.P.Santana 135 & 30609 \\
\hline Campylocentrum crassirhizum Hoehne & Epi & Ane & Native & - & J.P.Santana 106 & 29972 \\
\hline Catasetum uncatum Rolfe. & Epi & Ane & Native & M. Atla & T.R.Silva 29 & 26147 \\
\hline Cyrtopodium holstii L.C. Menezes & Her & Ane & Native & - & J.P.S.Santos 44 & 28439 \\
\hline Dimerandra emarginata (G.Mey.) Hoehne & Epi & Ane & Native & - & J.P.Santana 178 & 30844 \\
\hline Epidendrum strobiliferum Rchb.f.* & Epi & Ane & Native & & J.P.Santana 180 & 30846 \\
\hline Habenaria trifida Kunth & Her & Ane & Native & - & J.P.S.Santos 43 & 28438 \\
\hline Leochilus labiatus (Sw.) kuntze.* & Epi & Ane & Native & & J.P.Santana 282 & 33413 \\
\hline Oeceoclades maculata (Lindl.) Lindl. & Her & Ane & Natur & - & J.P.Santana 78 & 29651 \\
\hline Polystachya estrellensis Rchb.f. & Epi & Ane & Native & - & J.P.Santana 57 & 29045 \\
\hline Sacoila lanceolata (Aubl.) Garay & Her & Ane & Native & - & J.P.S.Santos 46 & 28441 \\
\hline Vanilla palmarum (Salzm. ex Lindl.) Lindl. & Clim & Ane & Native & - & T.R.Silva 53 & 26989 \\
\hline \multicolumn{7}{|l|}{ Oxalidaceae } \\
\hline Oxalis barrelieri L.* & Her & Aut & Native & - & J.P.Santana 123 & 30597 \\
\hline \multicolumn{7}{|l|}{ Passifloraceae } \\
\hline Passiflora foetida $\mathrm{L}$. & Clim & Zooc & Native & - & J.P.Santana 167 & 30745 \\
\hline Passiflora mansoi (Mart.) Mast.* & Clim & Zooc & Native & - & J.P.Santana 112 & 29978 \\
\hline Passiflora silvestris Vell. & Clim & Zooc & Native & - & J.P.Santana 164 & 25284 \\
\hline \multicolumn{7}{|l|}{ Phytolaccaceae } \\
\hline Petiveria alliacea Lin.* & Her & - & Native & - & J.P.Santana 55 & 29042 \\
\hline Rivina humilis $\mathrm{L}$. & Her & Zooc & Native & - & J.P.S.Santos 19 & 26121 \\
\hline \multicolumn{7}{|l|}{ Piperaceae } \\
\hline Peperomia pellucida (L.) Kunth & Her & - & Native & - & J.P.Santana 248 & 32651 \\
\hline Peperomia magnoliifolia (Jacq) A. Dietr. & Her & - & Native & - & J.P.Santana 97 & 29963 \\
\hline Piper amalago L.* & Shr & Zooc & Native & - & J.P.S.Santos 34 & 25303 \\
\hline \multicolumn{7}{|l|}{ Plantaginaceae } \\
\hline Stemodia foliosa Benth. & Her & Aut & Native & - & J.P.Santana 60 & 29048 \\
\hline \multicolumn{7}{|l|}{ Poaceae } \\
\hline Pappophorum pappiferum (Lam.)* & Her & Ane & Native & - & J.P.Santana 124 & 30598 \\
\hline Parodiolyra ramosissima (Trin.)* & Her & Zooc & Native & M. Atla & D.A.Campos 114 & 25297 \\
\hline Paspalum maritimum Trin. & Her & Aut & Native & - & T.R.Silva 102 & 27625 \\
\hline Setaria parviflora (Poir.) Kerguélen & Her & Ane & Native & - & J.P.Santana 121 & 30595 \\
\hline $\begin{array}{l}\text { Urochloa brizantha (Hochst. ex A. Rich.) R.D. } \\
\text { Webster. Webster }\end{array}$ & Her & Ane & Natur & - & T.R.Silva 139 & 28431 \\
\hline \multicolumn{7}{|l|}{ Polygalaceae } \\
\hline Securidaca diversifolia (L.) S.F. Blake. & Clim & Ane & Native & - & T.R.Silva 86 & 27371 \\
\hline \multicolumn{7}{|l|}{ Pontederiaceae } \\
\hline $\begin{array}{l}\text { Heteranthera oblongifolia C. Mart. ex Roem. \& } \\
\text { Schult. }\end{array}$ & Her & Hidr & Native & - & J.P.Santana 171 & 30749 \\
\hline Heteranthera reniformis Ruiz \& Pav. & Her & Hidr & Native & - & J.P.Santana 176 & 30842 \\
\hline \multicolumn{7}{|l|}{ Rhamnaceae } \\
\hline Ziziphus joazeiro Mart. & Shr & Zooc & Native & - & - & - \\
\hline \multicolumn{7}{|l|}{ Rubiaceae } \\
\hline Borreria humifusa Mart. & Her & Aut & Native & M. Atla & J.P.Santana 161 & 30739 \\
\hline Chiococca alba (L.) Hitchc. & Her & Zooc & Native & - & J.P.Santana 76 & 29649 \\
\hline Chomelia pubescens Cham. \& Schltdl* & Shr & Zooc & Native & - & J.P. Santana 327 & 29381 \\
\hline Chomelia obtusa Cham. \& Schltdl. & Shr & Zooc & Native & - & T.R.Silva 24 & 27383 \\
\hline Coutarea hexandra (Jacq.) Schum. & Shr & Zooc & Native & - & T.R.Silva 150 & 29057 \\
\hline Emmeorhiza umbellata (Spreng.) K. Schum. & Her & Zooc & Native & - & T.R.Silva 76 & 27058 \\
\hline Genipa americana $\mathrm{L}$. & Tre & Zooc & Native & - & T.R.Silva 39 & 25446 \\
\hline Guettarda sericea Muell & Shr & Zooc & Native & Caat & J.P.Santana 160 & 30738 \\
\hline Psychotria bracteocardia (DC.) Müll. Arg. & Her & Zooc & Native & - & J.P.Santana 84 & 29657 \\
\hline Psychotria capitata Ruiz \& Pavan & Her & Zooc & Native & - & T.R.Silva 119 & 28204 \\
\hline Psychotria carthagenensis Jacq. & Her & Zooc & Native & - & J.P.Santana 159 & 30737 \\
\hline Randia armata (Sw.) DC. & Her & Zooc & Native & - & J.P.Santana 116 & 29982 \\
\hline Sabicea grisea Cham. \& Schltdl. & Clim & Zooc & Native & - & J.P.Santana 108 & 29974 \\
\hline Tocoyena formosa (Cham. \& Schltdl.) K. Schum. & Shr & Zooc & Native & - & T.R.Silva 112 & 25289 \\
\hline \multicolumn{7}{|l|}{ Rutaceae } \\
\hline Ertela trifolia $($ L.) Kuntze & Her & Aut & Native & - & T.R.Silva 69 & 27051 \\
\hline Zanthoxylum sp.<> & Shr & Zooc & Native & M. Atl SE & J.P.Santana 109 & 29975 \\
\hline Salicaceae & & & & & & \\
\hline
\end{tabular}




\begin{tabular}{|c|c|c|c|c|c|c|}
\hline Casearia guianensis (Aubl.) Urb.* & Arb & Zooc & Native & - & J.P.Santana 408 & 36543 \\
\hline Casearia sylvestris $\mathrm{Sw}$. & Shr & Zooc & Native & - & T.R.Silva 06 & 25283 \\
\hline Prockia crucis P. Browne ex L. & Shr & Zooc & Native & - & J.P.Santana 62 & 29050 \\
\hline \multicolumn{7}{|l|}{ Santalaceae } \\
\hline Phoradendron piperoides HBK & Hem & Zooc & Native & - & J.P.Santana 72 & 29380 \\
\hline \multicolumn{7}{|l|}{ Sapindaceae } \\
\hline $\begin{array}{l}\text { Allophylus edulis (A. St.-Hil., Cambess. \& A. } \\
\text { Juss.) Radlk. }\end{array}$ & Tre & Zooc & Native & - & T.R.Silva 149 & 29056 \\
\hline Allophylus racemosus $\mathrm{Sw} . *$ & Shr & Zooc & Native & - & J.P.Santana 73 & 29384 \\
\hline Cupania impressinerviaAcev.-Rodr. & Tre & Zooc & Native & M. Atla & T.R.Silva 48 & 25455 \\
\hline Cupania oblongifolia Mart.* & Tre & Zooc & Native & - & J.P.S.Santos 12 & 26990 \\
\hline Matayba guianensis Aubl.* & Tre & Zooc & Native & & J.P.Santana 271 & 33402 \\
\hline Paullinia pinnata $\mathrm{L}$. & Clim & Zooc & Native & - & T.R.Silva 101 & 27624 \\
\hline Paullinia revoluta Radlk.* & Clim & Zooc & Native & & J.P.Santana 101 & 29967 \\
\hline Serjania communis Cambess.* & Clim & Ane & Native & & J.P.Santana 281 & 33412 \\
\hline Serjania salzmanniana Schltr. & Clim & Ane & Native & - & T.R.Silva 80 & 27062 \\
\hline \multicolumn{7}{|l|}{ Sapotaceae } \\
\hline Pouteria grandiflora (A.DC.) Baehni & Tre & Zooc & Native & M. Atla & J.P.Santana 103 & 29969 \\
\hline Sideroxylon obtusifolium (Roem \& Schutt) Penn. & Shr & Zooc & Native & - & T.R.Silva 105 & 27629 \\
\hline \multicolumn{7}{|l|}{ Solanaceae } \\
\hline Aureliana fasciculata (Vell) Sendth* & Shr & Zooc & Native & - & J.P.Santana 115 & 29981 \\
\hline Brunfelsia uniflora (Pohl) D. Dom.* & Tre & Zooc & Native & - & J.P.Santana 285 & 33416 \\
\hline Solanum paludosum Moric. & Her & Zooc & Native & - & D.A.Campos 116 & 25299 \\
\hline Solanum rhytidoandrum Sendtn.* & Her & Zooc & Native & - & J.P.Santana 65 & 29058 \\
\hline Solanum sp. & Her & Zooc & Native & - & J.P.Santana 102 & 29968 \\
\hline \multicolumn{7}{|l|}{ Trigoniaceae } \\
\hline Trigonia nivea Cambess. var. nivea & Shr & Ane & Native & - & D.A.Campos 111 & 25294 \\
\hline \multicolumn{7}{|l|}{ Turneraceae } \\
\hline Turnera subulata $\mathrm{Sm}$. & Clim & Zooc & Native & - & T.R.Silva 49 & 25456 \\
\hline \multicolumn{7}{|l|}{ Urticaceae } \\
\hline Cecropia pachystachya Trécul & Tre & Zooc & Native & - & J.P.Santana 299 & 33420 \\
\hline \multicolumn{7}{|l|}{ Verbenaceae } \\
\hline Lantana achyranthifolia Desf.* & Her & Zooc & Native & - & J.P.S.Santos 05 & 26100 \\
\hline Lantana camara $\mathrm{L}$. & Her & Zooc & Native & - & J.P.S.Santos 35 & 25298 \\
\hline Lantana canescens Kunth. & Her & Zooc & Native & - & J.P.S.Santos 08 & 26102 \\
\hline Lantana radula $\mathrm{Sw} . *$ & Her & Zooc & Native & - & D.A.Campos 113 & 25296 \\
\hline Priva bahiensis P.DC. & Her & Aut & Native & Nord & J.P.Santana 59 & 29047 \\
\hline Stachytarpheta cayennensis Vahl & Her & Aut & Native & - & T.R.Silva 27 & 26145 \\
\hline \multicolumn{7}{|l|}{ Violaceae } \\
\hline Pombalia calceolaria (L.) Paula-Souza & Her & Aut & Native & - & J.P.Santana 52 & 29039 \\
\hline \multicolumn{7}{|l|}{ Angiosperms/Exotic and Grown } \\
\hline Family/Species & Habitat & Dispr & Origin & End & V.(ASE) & \\
\hline \multicolumn{7}{|l|}{ Anacardiaceae } \\
\hline Mangifera indica $\mathrm{L}$. & Tre & Zooc & Exot & - & - & - \\
\hline \multicolumn{7}{|l|}{ Arecaceae } \\
\hline Roystonea oleracea (Jacq.) O.F. Cook. & Tre & Zooc & Exot & - & - & - \\
\hline \multicolumn{7}{|l|}{ Asparagaceae } \\
\hline Sansevieria trifasciata Prain & Her & Zooc & Exot & - & - & - \\
\hline \multicolumn{7}{|l|}{ Combretaceae } \\
\hline Terminalia catappa $\mathrm{L}$. & Tre & Zooc & Exot & - & - & - \\
\hline \multicolumn{7}{|l|}{ Fabaceae } \\
\hline Acacia auriculiformis A. Cunn. ex Benth. & Tre & Zooc & Exot & - & T.R.Silva 116 & 27640 \\
\hline Acacia mangium Willd. & Tre & Zooc & Exot & - & J.P.S.Santos 37 & 26141 \\
\hline Adenanthera pavonina $\mathrm{L}$. & Tre & Aut & Exot & - & J.P.Santana 56 & 29043 \\
\hline Delonix regia (Bojer ex Hook.) Raf. & Tre & Aut & Cult & - & T.R.Silva 96 & 27385 \\
\hline Tamarindus indica $\mathrm{L}$ & Shr & Zooc & Cult & - & - & - \\
\hline Malvaceae & & & & & & \\
\hline Hibiscus mutabilis $\mathrm{L}$. & Tre & - & Cult & - & T.R.Silva 100 & 27623 \\
\hline Moraceae & & & & & & \\
\hline Ficus nitida Thunb. & Tre & Zooc & Exot & - & T.R.Silva 20 & 26113 \\
\hline Moringaceae & & & & & & \\
\hline Moringa oleifera Lam. & Tre & Ane & Exot & - & T.R.Silva 88 & 27373 \\
\hline Myrtaceae & & & & & & \\
\hline
\end{tabular}


Floristic characterization...

SANTANA, J. P. et al.

\begin{tabular}{|c|c|c|c|c|c|c|}
\hline Eucalyptus torelliana $\mathrm{F}$. Muell & Tre & Aut & Exot & - & - & - \\
\hline Eucalyptus citriodora Hook. & Tre & Aut & Exot & - & G.Viana 913 & 3744 \\
\hline \multicolumn{7}{|l|}{ Oleaceae } \\
\hline Jasminum azoricum $\mathrm{L}$. & Clim & Zooc & Exot & - & J.P.Santana 165 & 30743 \\
\hline \multicolumn{7}{|l|}{ Rubiaceae } \\
\hline Ixora coccinea $\mathrm{L} .$. & Her & Zooc & Cult & - & T.R.Silva 83 & 27368 \\
\hline \multicolumn{7}{|l|}{ Sapotaceae } \\
\hline Manilkara zapota (L.) P.Royen & Tre & Zooc & Cult & - & J.P.Santana 262 & 32565 \\
\hline \multicolumn{7}{|l|}{ Solanaceae } \\
\hline Cestrum nocturnum L. & Her & Zooc & Exot & - & T.R.Silva 52 & 26988 \\
\hline \multicolumn{7}{|l|}{ Zingiberaceae } \\
\hline Alpinia zerumbet (Pers.) B.L. Burtt \& R.M. Sm. & Her & Zooc & Cult & - & T.R.Silva 35 & 25442 \\
\hline
\end{tabular}

